\title{
25(OH) VITAMIN D DEFICIENCY IN CYSTIC FIBROSIS CHILDREN - A PROSPECTIVE STUDY ON PREVALENCE AND TREATMENT OUTCOME
}

\author{
IUSTINA VIOLETA STAN ${ }^{1,2 \#}$, ANCA BĂLĂNESCU ${ }^{1,2}$, IOANA FLORENTINA CODREANU ${ }^{1,2 *}$, \\ ALINA ANGELICA BELIVACA ${ }^{1,2}$, MIRELA ELENA RITIVOIU ${ }^{1,2 \#}$, MARIANA MĂDĂLINA \\ DRĂGOI $^{2}$, SILVIU ADRIAN MARINESCU ${ }^{1,3 \#}$, CHANER ALI ${ }^{2}$, VALENTINA DANIELA \\ COMĂNICI ${ }^{1,2}$
}

\footnotetext{
1 "Carol Davila” University of Medicine and Pharmacy, 8 Eroii Sanitari Boulevard, Bucharest, Romania

2 "Alessandrescu-Rusescu” Mother and Child's Health National Institute, 120 Lacul Tei Boulevard, Bucharest, Romania

3 "Bagdasar-Arseni” Emergency Clinical Hospital, Department of Plastic and Reconstructive Surgery, 12 Berceni Road, Bucharest, Romania
}

*corresponding author: dr.ioanacodreanu@gmail.com

\#Authors with equal contribution

Manuscript received: November 2018

\begin{abstract}
Cystic fibrosis (CF) patients have a high risk of vitamin D deficiency due to malabsorption. The aim of the study was to evaluate the prevalence of $25(\mathrm{OH})$ vitamin $\mathrm{D}$ deficiency in a paediatric $\mathrm{CF}$ cohort and the outcome of vitamin $\mathrm{D}_{3}$ treatment. We conducted a prospective "before-after" cohort study on 65 children diagnosed with CF. Patient assessment included anthropometric measurements, pulmonary function tests and serum vitamin D level assessment at visit one and 6 months later at visit 2 for patients with vitamin D deficiency. A serum level below $74 \mathrm{nmol} / \mathrm{L}$ was considered vitamin $\mathrm{D}$ deficiency. The study revealed a high prevalence of vitamin $\mathrm{D}_{3}$ deficiency $(61.6 \%)$ in CF patients. Treatment with high doses of vitamin $\mathrm{D}_{3}$ had a good therapeutic response with statistically significant changes of serum levels of $25(\mathrm{OH})$ vitamin $\mathrm{D}$, but not with the expected efficiency.
\end{abstract}

\section{Rezumat}

Pacienții cu fibroză chistică (FC) prezintă risc crescut pentru deficit de $25(\mathrm{OH})$ vitamina D secundar malabsorbției. Scopul studiului a fost să evalueze prevalența deficitului de vitamina D la pacienții pediatrici cu FC și răspunsul terapeutic la tratamentul cu vitamina $\mathrm{D}_{3}$. Am efectuat un studiu de cohortă prospectiv tip ,înainte-după” pe 65 de copii diagnosticați cu FC. S-au efectuat măsurători antropometrice, probe funcționale respiratorii și determinarea concentraţiei serice vitaminei D la vizitele 1 și 2, la interval de 6 luni, pentru cei cu deficit de vitamina D (sub $74 \mathrm{nmol} / \mathrm{L}$ ). Studiul a arătat o prevalență crescută a deficitului de vitamina $\mathrm{D}(61,6 \%)$ la pacienții cu FC. Tratamentul cu vitamina $\mathrm{D}_{3}$ în doză mare a avut răspuns terapeutic cu modificări semnificativ statistice ale nivelurilor serice ale $25(\mathrm{OH})$ vitaminei $\mathrm{D}$, dar nu cu eficiența scontată.

Keywords: cystic fibrosis, vitamin D deficiency, vitamin $\mathrm{D}_{3}$

\section{Introduction}

Vitamin D is a fat-soluble vitamin with an important role in calcium and phosphorus homeostasis involved in the process of normal mineralization of matrix collagen I in bones. It also plays an important role in bones' metabolism and normal development of muscles in children [11, 26, 29].

Vitamin $\mathrm{D}$ is found as vitamin $\mathrm{D}_{2}$ form (ergocalciferol) in vegetable products and vitamin $\mathrm{D}_{3}$ (cholecalciferol) in animal products. Vitamin D synthesis is triggered by sun exposure via UVB (ultraviolet radiation B) [21] at skin level [7, 8]. Vitamin D binds to an alphaglobulin - Vitamin D Binding Protein (DBP) and is transported to the liver where it's hydroxylated in the $25^{\text {th }}$ position, resulting in $25(\mathrm{OH})$ vitamin $\mathrm{D}$ (calcidiol), an inactive but stable form of vitamin D.
Calcidiol is hydroxylated to its active unstable form, $1 \alpha, 25(\mathrm{OH}) 2$ vitamin $\mathrm{D}_{3}$ (calcitriol) in the proximal convoluted tubules of the kidneys. This process can also occur in other cell types (endothelial, beta, of the immune system). DBP is very important for calcitriol and calcidiol measurement in children [21, 30]. Although biologically inactive, $25(\mathrm{OH})$ vitamin D has a half-life of about 2 - 3 weeks and it's poorly influenced by serum calcium, phosphorus and parathyroid hormone (PTH). Its level is used as a functional indicator for vitamin $\mathrm{D}$ status monitoring $[4,30,31]$.

Although there are differences of opinion, the American Society of Endocrinology and the American Pediatric Society state that $25(\mathrm{OH})$ vitamin D levels below 20 $\mathrm{ng} / \mathrm{mL}(50 \mathrm{nmol} / \mathrm{L})$ are considered deficiency, levels 
FARMACIA, 2019, Vol. 67, 3

between 21 and $29 \mathrm{ng} / \mathrm{mL}(52.5-72.5 \mathrm{nmol} / \mathrm{L})$ are considered insufficiency and levels over $30 \mathrm{ng} / \mathrm{mL}$ $(>75 \mathrm{nmol} / \mathrm{L})$ are considered sufficient $[4,31]$.

Vitamin D deficiency is a general problem among the paediatric population. In Romania, vitamin $\mathrm{D}_{3}$ prophylaxis (400 - $800 \mathrm{IU})$ is recommended up to 18 months of age and afterwards during the cold season $[14,16]$.

A special category of patients at high risk for vitamin D deficiency are CF children [5]. CF (OMIM 219700) [14] is the most common monogenic disease with autosomal recessive transmission. Its incidence in Europe is 1:2000 - 1:3000 new-borns (carrier state 1:24 - 1:25 new-borns) with significant ethnic variations [17]. CF is a multisystemic disease that affects the upper and lower respiratory tracts, the digestive system (including liver and gallbladder, pancreas) associating exocrine pancreatic insufficiency and secondary endocrine involvement, male infertility $[12,34]$.

One of the core features in $\mathrm{CF}$ is the presence of malabsorption due to exocrine pancreatic insufficiency. Therefore, despite supplementing with dedicated formulas, it often associates significant deficiencies in fat soluble vitamins, especially vitamin D [27]. This is of great interest in CF because circulating vitamin $\mathrm{D}$ levels are associated with pulmonary function, the increase of number of annual exacerbations [22, 45], bone mass development and immune response efficiency [5,27].

The most common manifestations of vitamin D deficiency in these patients are osteoporosis (10 $34 \%$ ) and osteopenia (85\% in CF adults). These are due to deficient absorption of vitamins $\mathrm{D}$ and $\mathrm{K}$, prolonged immobilization, lack of sun exposure, corticosteroid therapy, delayed puberty and the systemic effect of proinflammatory cytokines $[9,11,12,34]$. CF guidelines highlight the importance of annual screening of vitamin D deficiency, dietary supplementation, irrespective of age and season, along with Pancreatic Enzyme Replacement Therapy (PERT) [5, 18, 28]. Pancreatic enzymes may be permanently administered depending on age or fat content per meal (3000 $4000 \mathrm{IU}$ lipase/1 g fat). Fat-soluble vitamins A, D, $\mathrm{E}$ and $\mathrm{K}$ supplementation are also recommended permanently $[2,7]$.

CF guidelines recommend vitamin $D_{3}$ supplementation depending on age, as follows: for infants $10 \mathrm{mcg}$ (400 - 500 IU) per day, and 10 - $20 \mathrm{mcg}(800$ - 2000 IU) per day for children older than 12 months $[5,6$, $38,44]$.

A minimum serum level of $30 \mathrm{ng} / \mathrm{mL}(75 \mathrm{nmol} / \mathrm{L})$ vitamin $\mathrm{D}$ is recommended to be maintained in $\mathrm{CF}$ patients. Achieving and maintaining this level is often difficult, thus multiple treatment options have been proposed [3, 41].

Low vitamin D levels are associated with a higher risk of fractures, kyphosis and pulmonary function decline, which correlate with increased morbidity and mortality [12,35].

Considering all the above, the main aim of the study was to evaluate the prevalence of $25(\mathrm{OH})$ vitamin $\mathrm{D}$ deficiency in a paediatric CF cohort and the outcome of vitamin $\mathrm{D}_{3}$ supplementation. The second objective was to evaluate the association between $25(\mathrm{OH})$ vitamin D levels and certain clinical characteristics, and patients' adherence to PERT.

\section{Materials and Methods}

\section{Study design and patient study population}

We have conducted a prospective "before-after" cohort study that included 65 children diagnosed with CF and monitored in our Regional CF Center at Mother and Child's Health National Institute "AlessandrescuRusescu" (INSMC), Bucharest, Romania.

Patient enrolment was conducted over a period of 1 year $\left(1^{\text {st }}\right.$ of January $2016-1^{\text {st }}$ of January 2017). The inclusion criteria were: children diagnosed with CF (two positive sweat tests, with chloride sweat value $>60 \mathrm{mEq} / \mathrm{L}$ and/or molecular diagnose) aged between 2 and 18 years. Patients who failed to meet all the diagnosis criteria were not included in the study. Also, patients under the age of 2 were excluded from the study as most of them were either exclusively artificially fed or they were being given fortified milk which added an additional intake of vitamin D.

For all our patients genotyping was performed previously to study enrolment as per diagnosis guidelines. Our local laboratory determined Cystic Fibrosis Transmembrane Conductance Regulator (CFTR) gene mutation based on polymerase chain reaction (PCR) and reverse hybridization using the CF genetic Assay Nuclear Laser Medicine genotyping kit provided by Nuclear Laser Medicine, Settala, Italy. The kit is certified for in vitro diagnosis and evaluates 38 mutations and one polymorphism of the CFTR gene: F508del (delta F508), I507del, F508C.I502T, 1706del17, 1677delTA, G542X, 1717-1G >A, R553X, Q552X, G551D, S549R(A>C), N1303K, 4016insT, R1162X, R1158X, W1282X, G1244E, 2789+5G $>$ A, $711+1 \mathrm{G}>\mathrm{T}, \quad \mathrm{G} 85 \mathrm{E}, \quad 3849+10 \mathrm{kbC}>\mathrm{T}, \quad 621+1 \mathrm{G}>\mathrm{T}$, R117H, D1152H, L1065P, R1066H, L1077P, 4382delA, 1259insA, 852del22, R347P, T338I, S912X, I148T, 3199de16, Allele 5T-7T-9T.

Written informed consent was signed for each child by their parent or legal guardian. The study was approved by the local Ethics Committee of INSMC.

We performed clinical evaluation for each patient. Patient assessment included anthropometric measurements (weight $(\mathrm{kg}), \mathrm{Z}$ score - weight; height $(\mathrm{cm}), \mathrm{Z}$ score height; Body Mass Index (BMI) $\left(\mathrm{kg} / \mathrm{m}^{2}\right), \mathrm{Z}$ score BMI). Values of Forced Expiratory Volume in the first second (FEV1\%) were registered. Unfortunately, pulmonary function tests were only available for older children who could cooperate and perform 
successful spirometry manoeuvres. Adherence to PERT was assessed.

Sample collection and serum vitamin $D$ assessment $25(\mathrm{OH})$ vitamin D serum levels were assessed in all patients along with other biological parameters required by official guidelines $[5,6,16,18]$. In order to determine the effectiveness of therapeutic intervention, patients who initially had vitamin D deficiency were re-evaluated after a 6 months follow-up. PERT adherence was also re-evaluated.

The blood samples were collected and processed in the local laboratory. Serum $25(\mathrm{OH})$ vitamin D was evaluated using an Enzyme Linked Fluorescent Assay technique (ELFA). In this purpose we used a VIDAS ${ }^{\circledR}$ 25(OH) Vitamin D Total kit provided by Biomerieux. This is an automated quantitative test for human plasma or serum samples based on a sequential competitive immunoassay. In order to separate $25(\mathrm{OH})$ vitamin $\mathrm{D}$ from its binding protein, the sample was mixed with a pre-treatment reagent which was afterwards collected and transferred into a well, containing the conjugate alkaline-phosphatase-labelled anti-vitamin $\mathrm{D}$ antibody. In this manner the vitamin $\mathrm{D}$ antigen of the sample and the vitamin D antigen coating the interior of the SPR were to compete for binding sites on the conjugate. In the final step of the assay the substrate (4-methylumbelliferyl phosphate) was cycled in and out of the SPR. The substrate was catalysed into a fluorescent product measurable at $450 \mathrm{~nm}$. The intensity of the sample was inversely proportional to the vitamin $\mathrm{D}$ antigen concentration of the sample. The results with respect to the calibration curve were automatically calculated [24].

In order to evaluate the therapeutic response, a second blood sample was drawn after 6 months of treatment in patients with initial vitamin D deficiency.

Seasonal blood sample drawing was respected. All initial vitamin $\mathrm{D}$ determinations were performed at the end of the winter. We considered serum vitamin $\mathrm{D}$ levels higher than $74 \mathrm{nmol} / \mathrm{L}$ normal, levels ranging from 20 to $74 \mathrm{nmol} / \mathrm{L}$ - moderate vitamin D deficiency, and below $20 \mathrm{nmol} / \mathrm{L}$ - severe vitamin D deficiency. Vitamin $\mathrm{D}_{3}$ supplementation was performed according to the recommendations for age and deficiency level $[6,37]$. Patients between 2 and 10 years of age with severe deficiency received 4000 IU daily, whereas those with moderate deficiency received 2000 IU daily. Patients older than 10 years with severe deficiency received 6000 IU per day, whereas those with moderate deficiency received 4000 IU per day.

Statistical analysis

Differences between groups were evaluated using non-parametric tests for continuous variables (MannWhitney $\mathrm{U}$ for non-paired variables and Wilcoxon tests for paired variables) and chi-square tests for nominal variables. Microsoft Excel and SPSS version 16 for Windows were used for statistical analysis.

\section{Results and Discussion}

A total of 65 patients were enrolled in the study with a median age of 8 years old (minimum 2 years maximum 18 years) - Figure 1.35 out of 65 (53.8\%) were boys. 27 subjects $(41.5 \%)$ were F508del homozygous. Table I presents descriptive data of the recruited patients.

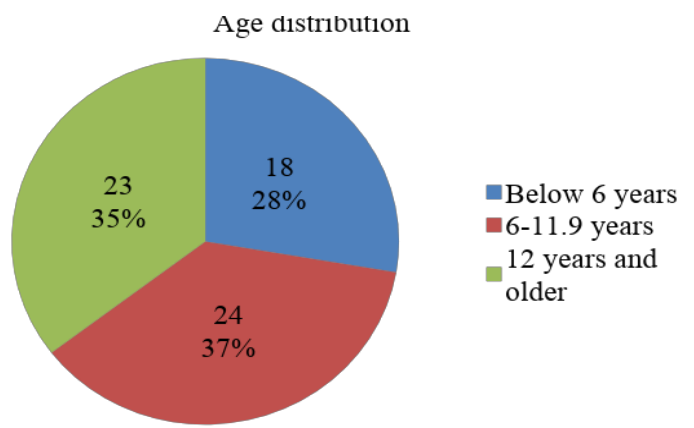

Figure 1.

Age distribution of the studied population

Only one-third of the patients were able to correctly complete a spirometry test (younger patients do not cooperate for spirometry).

Prevalence of vitamin D deficiency was $61.6 \%$ with $6.2 \%$ of patients having severe vitamin D deficiency and $55.4 \%$ having moderate vitamin D deficiency.

Out of the 40 patients who had vitamin D deficiency at the first determination 31 , of them remained unresponsive, to vitamin $\mathrm{D}_{3}$ supplementation, maintaining the deficiency. After 6 months of follow-up, only one of the unresponsive patients remained in the subgroup of severe vitamin D deficiency.

Thus, the prevalence of vitamin D deficiency decreased from $61.6 \%$ to $47.6 \%$ in the entire group of patients after receiving the high dose of vitamin D (Figure 2).

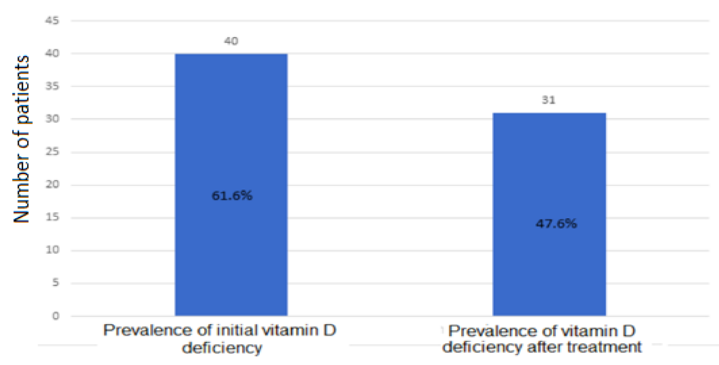

Figure 2.

Vitamin D treatment efficiency in the studied group of patients 
Table I

Descriptive characteristics of the cohort

\begin{tabular}{|c|c|c|c|}
\hline Parameter & \multicolumn{3}{|c|}{$\mathrm{N}=65$} \\
\hline Male gender $(\mathrm{n}, \%)$ & \multicolumn{3}{|c|}{$35(53.8 \%)$} \\
\hline Age (years) - median (min - max) & \multicolumn{3}{|c|}{$8(2-18)$} \\
\hline Serum vitamin D level median $(\min -\max )$ & \multicolumn{3}{|c|}{$67(20-215) \mathrm{nmol} / \mathrm{L}$} \\
\hline \multirow{2}{*}{ Severity of vitamin $\mathrm{D}_{3}$ deficiency (n, \%) } & Severe & Moderate & Without deficiency \\
\hline & $4(6.2 \%)$ & $36(55.4 \%)$ & $25(38.4 \%)$ \\
\hline Patients following vitamin D supplementation (n, \%) & \multicolumn{3}{|c|}{$40(61.6 \%)$} \\
\hline Status of homozygous Delta F508 (n, \%) & \multicolumn{3}{|c|}{$27(41.5 \%)$} \\
\hline Patients with associated infections (n, \%) & \multicolumn{3}{|c|}{$2(3.1 \%)$} \\
\hline PERT compliance (n, \%) & \multicolumn{3}{|c|}{$55(84.6 \%)$} \\
\hline Pulmonary damage - FEV $1<70 \%(\mathrm{n}, \%)$ & \multicolumn{3}{|c|}{$2(9.5 \%)$} \\
\hline BMI $\left(\mathrm{kg} / \mathrm{m}^{2}\right)-\operatorname{median}(\min -\max )$ & \multicolumn{3}{|c|}{$14.89(11.64-22.31)$} \\
\hline Z-score BMI - median (min - $\max )$ & \multicolumn{3}{|c|}{$-0.96(-5.61--0.16)$} \\
\hline Z-score height - median ( $\min -\max )$ & \multicolumn{3}{|c|}{$-0.40(-3.5-1.94)$} \\
\hline Z-score weight - median (min - $\max )$ & \multicolumn{3}{|c|}{$-0.59(-3.5-0.89)$} \\
\hline FEV1\% predicted - median (min - max) & \multicolumn{3}{|c|}{$88.9 \%(32 \%-118 \%)$} \\
\hline Infectious exacerbation/12 months - median (min - max) & \multicolumn{3}{|c|}{$0(0-3)$} \\
\hline Patients who performed spirometry (n, \%) & \multicolumn{3}{|c|}{$21(32.3 \%)$} \\
\hline
\end{tabular}

PERT - Pancreatic Enzyme Replacement Therapy, BMI - Body Mass Index, FEV1 - Forced Expiratory Volume in 1 second

Patients with vitamin D deficiency tended to be older than the subgroup of patients without vitamin deficiency $($ median $=9.5$ years, minimum 2 years maximum 18 years versus median $=7$ years, minimum 2 years - maximum 16 years, $\mathrm{p}=0.12$, test MannWhitney U) - Figure 3.

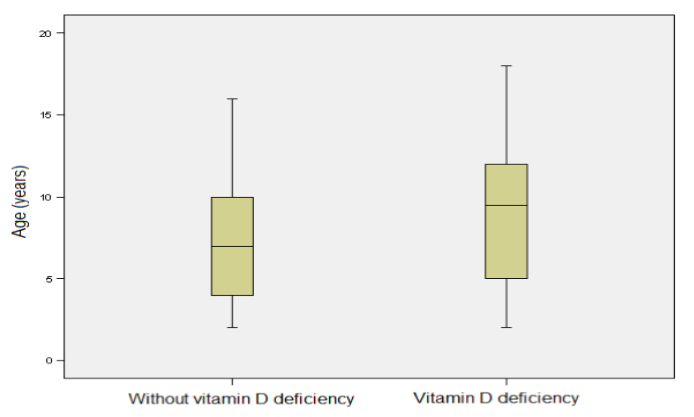

Figure 3.

Comparison between the age distribution in patients with and without vitamin D deficiency

It was noticed a correlation between the lack of compliance to replacement enzymatic therapy and vitamin D deficiency, in the subgroup of patients with vitamin $\mathrm{D}$ deficiency it has been observed a tendency of low compliance to PERT - 8 patients, $80 \%$ versus 32 patients, $52 \%$ ), $\mathrm{p}=0.19$, Chi-square test.

A tendency for vitamin D deficiency was observed in male patients (25 patients, $71.4 \%$ versus 15 patients, $50 \%$ ) - $\mathrm{p}=0.07$, Chi-square test.

There were no statistically significant differences between clinical characteristics of responders and non-responders to vitamin $\mathrm{D}_{3}$ supplementation therapy. High dose vitamin $\mathrm{D}_{3}$ therapy resulted in a significant increase in the serum concentration 6 months after initiation of therapy $(p=0.01$, paired Wilcoxon test,
Figure 4). The pre therapeutic level of vitamin D had a median of $57.5 \mathrm{nmol} / \mathrm{L}$ (minimum 20 - maximum $71 \mathrm{nmol} / \mathrm{L}$ ), subsequently increasing under therapy to a range of normal values, but maintaining a median of 57.2 (minimum 20.2 - maximum $161 \mathrm{nmol} / \mathrm{L}$ ).

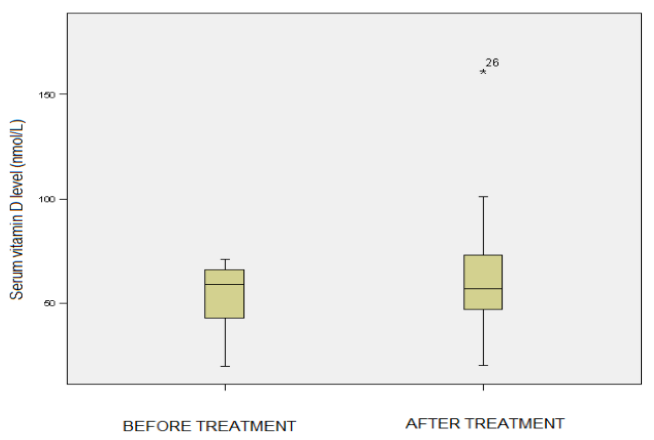

Figure 4.

Vis Comparison between serum levels of Vitamin D before and after therapy

At the same time, a negative correlation between age and FEV $1 \%$ was observed $(\mathrm{r}=-0.43, \mathrm{p}=0.04$, Kendall-Tau correlation test), FEV1\% decreasing with age.

The aetiology of vitamin D deficiency in CF is multifactorial: deficient absorption due to exocrine pancreatic insufficiency, decreased 25-hydroxylation of vitamin D, increased excretion through enterohepatic dumping [20], low DBP levels [8, 33] insufficient sunlight exposure (multiple hospitalizations, avoiding sunlight exposure in patients with antibiotic related photo-sensibility), decrease of vitamin D deposits due to low fat deposits and lack of compliance with vitamin $\mathrm{D}_{3}$ supplementation.

It is important to remember that the median BMI was 14.89 (weight deficit is defined by a BMI under 16). 
According to this parameter, the percentage of patients with weight deficit is much higher than the one considered by BMI Z-score (-0.96), the weight Zscore being far more influenced then the height $\mathrm{Z}$ score. This fact might suggest that the weight deficit would indirectly influence (through fat deposits) the level of vitamin D deficiency.

In our study group there was no statistically significant correlation between low levels of vitamin D and the BMI Z-score, height or weight Z-score.

There is agreement between scientists regarding the impact of vitamin D deficiency over pulmonary function in chronic obstructive pulmonary disease (COPD), asthma, diabetes mellitus or cardiovascular diseases. However, there is no such agreement in CF. There are conflicting results regarding the role played by vitamin $\mathrm{D}$ in $\mathrm{CF}$ patients pulmonary function. Although, some studies showed that vitamin D deficiency does not have an immunologic, antiinfectious or functional impact on CF patients' lungs [18, 23, 43], other studies state that vitamin D deficiency is associated with pulmonary dysfunction and lower FEV1\% [25].

Some studies show a positive correlation between vitamin D serum levels and pulmonary function and a negative correlation with airway inflammation and pulmonary infection [13]. Furthermore, higher vitamin D levels could be associated with fewer pulmonary exacerbations [1].

The results obtained in our study showed that there is no statistically significant association between low FEV1\% and vitamin D deficiency. However, it is important to remember that only a third of the patients had their pulmonary function tested due to technical difficulties (attempting spirometry on patients under 6 years old).

It is however possible for low vitamin D levels to correlate with the severity of bronchiectasis, as it is for patients with bronchiectasis of other aetiology than CF [10].

Of the patients with CF, $50 \%$ to $90 \%$ have vitamin D deficiency [25]. This was also confirmed by our study. In our study group, $61.6 \%$ of the patients with CF had vitamin D deficiency, in spite of proper intake and compliance with both treatment and enzymatic substitution.

Surprisingly, only $6.2 \%$ of these patients associate severe vitamin $\mathrm{D}$ deficiency. In the literature, the prevalence of severe vitamin D deficiency is between $15 \%$ and $23 \%$. Knowing that vitamin D deficiency is positively correlated with age [33], these differences could have occurred due to the age of the patients included in the study.

Once vitamin $\mathrm{D}_{3}$ supplementation was administered in accordance with the current recommendations, the percentage of patients with vitamin $\mathrm{D}$ deficiency decreased from $61.6 \%$ to $47.6 \%$, a rather disappointing result. The lack of compliance with the recommended treatment is suspected in patients who did not improve severe vitamin D deficiency [3]. It is therefore debatable whether applying other treatment regimens for vitamin $\mathrm{D}$ deficiency would be beneficial.

One of these regimens requires vitamin $\mathrm{D}_{3}$ administration depending on the severity of the deficiency and the age of the patient $[6,38,44]$. Patients with vitamin $\mathrm{D}$ levels below $75 \mathrm{nmol} / \mathrm{L}$ should receive median doses of vitamin D (preferably cholecalciferol) for 3 months. The patients under the age of 5 should to receive $12000 \mathrm{IU}$ per week and the ones over the age of 5 should receive 50000 IU per week. If after 3 months of treatment vitamin $\mathrm{D}$ levels remain below $75 \mathrm{nmol} / \mathrm{L}$, high doses of vitamin $\mathrm{D}_{3}$ will be administered for another 3 months. Patients under 5 years old will receive 12000 IU twice a week and those over 5 years old - 50000 IU twice a week [39]. However, this treatment regimen for vitamin D deficiency in CF still requires studies on large groups of patients for the evaluation of its efficiency as there are only few studies on this matter [32, 36, 40, 42].

Study limitation

The main limitation was the low number of patients in the recruited group which resulted in a low statistical power of the study. However, it should be underlined that the limited number of patients included in the study is due to the fact that $\mathrm{CF}$ is a rare genetic disease.

Another significant limitation is represented by the lack of complete information regarding pancreatic sufficiency/insufficiency - the local laboratory doesn't determine faecal pancreatic elastase. We mention that pancreatic replacement therapy is evaluated indirectly by monitoring pancreatic insufficiency - measuring free fat in the stool but faecal pancreatic elastase has higher sensitivity.

Spirometry could not be performed in preschool patients due to lack of adequate equipment on site.

\section{Conclusions}

We observed a high prevalence $(61.6 \%)$ of vitamin $\mathrm{D}$ deficiency in the studied population. High dose vitamin $\mathrm{D}_{3}$ treatment had a therapeutic response with statistically significant changes in serum levels of $25(\mathrm{OH})$ vitamin $\mathrm{D}$ before and after intervention (a decrease in vitamin D deficiency prevalence from $61.6 \%$ to $47.6 \%$ ). This was not the expected efficiency as not all of the patients reached normal vitamin D levels despite treatment according to international recommendations.

No statistically significant associations were found between vitamin $\mathrm{D}$ deficiency and clinical features of CF patients in the studied population.

However, a tendency of association between the lack of compliance to PERT and vitamin D deficiency has been observed. 


\section{References}

1. Abu-Fraiha Y, Elyashar-Earon H, Shoseyov D, Cohen-Cymberknoh M, Armoni S, Kerem E, Wilschanski M, Increasing vitamin D serum levels is associated with reduced pulmonary exacerbation in patients with cystic fibrosis. J Pediatr Gastroenterol Nutr., 2019; 68(1): 110-115.

2. Alicandro G, Bisogno A, Battezzati A, Bianchi ML, Corti F, Colombo C, Recurrent pulmonary exacerbations are associated with low fat free mass and low bone mineral density in young adults with cystic fibrosis. J Cystic Fibros., 2014; 13(3): 328-334.

3. Boyle MP, Noschese MI, Watts SL, Davis ME, Stennet SE, Lechtzin N, Failure of high dose ergocalciferol to correct vitamin deficiency in adult with cystic fibrosis. Am J Respir Crit Care Med., 2005; 172(2): 212-217.

4. Braegger C, Campoy C, Colomb V, Decsi T, Domellof M, Fewtrell M, Hojsak I, Mihatsch W, Molgaard C, Shamir R, Turck D, van Goudoever J, ESPGHAN Committee on Nutrition, Vitamin D in the healthy European paediatric population. $J$ Pediatr Gastroenterol Nutr., 2013; 56(6): 692-701.

5. Castellani C, Duff AJA, Bell SC, Heijerman HGM, Munck A, Ratjen F, Sermet-Gaudelus I, Southern KW, Barben J, Flume PA, Hodková P, Kashirskaya N, Kirszenbaum MN, Madge S, Oxley H, Plant B, Schwarzenberg SJ, Smyth AR, Taccetti G, Wagner TOF, Wolfe SP, Drevinek P, ECFS best practice guidelines: the 2018 revision. J Cyst Fibros, 2018; 17(2): 153-178.

6. Chesdachai S, Tangripcha V, Treatment of vitamin D deficiency in cystic fibrosis, $J$ Steroid Biochem Mol Biol., 2016; 164: 36-39.

7. Clinical Guidelines Care of Children with Cystic Fibrosis NHS, 2017, $7^{\text {th }}$ edition, www.rbht.nhs.uk.

8. Coppenhaver D, Kuepper F, Schidlow D, Bee D, Isenburg JN, Barnett DR, Bowman BH, Serum concentration of vitamin D- binding protein (groupspecific component) in cystic fibrosis, Hum Genet., 1981; 57(4): 399-403.

9. Elborn JS, Cystic fibrosis. The Lancet, 2016; 388 (10059): 2519-2531.

10. Ferri S, Crimi C, Heffler E, Campisi R, Noto A, Crimi N, Vitamin D and disease severity in bronchiectasis. Respir Med., 2019; 148: 1-5.

11. Grigorie D, Coles D, Caragheorgheopol A, Şucaliuc A, Vitamin D status and consequences of long term supplementation with oral native vitamin D3 on the severity of primary hyperparathyroidism - the Romanian experience. Farmacia, 2018; 66(5): 877-882.

12. Hall BW, Sparks AA, Aris MR, Vitamin D deficiency in cystic fibrosis. Int J Endocrinol., 2010; 2010: 1-9.

13. Herscovitch N, Dauletbaev N, Lands CL, Vitamin $\mathrm{D}$ as anti-microbial and anti-inflammatory therapy for cystic fibrosis. Paediatr Respir Rev., 2014, 15(2): 154-162.

14. www.omim.org.

15. Kanhere M, Chassaing B, Gewirtz AT, Tangpricha $\mathrm{V}$, Role of vitamin D on gut microbiota in cystic fibrosis. J Steroid Biochem Mol Biol., 2018; 175: 82-87.
16. Kerem E, Conway S, Elborn S, Heijerman H, Consensus Committee, Standards of care for patients with cystic fibrosis: a European consensus. J Cyst Fibros., 2005; 4(1): 7-26.

17. Kerem E, Kalman YM, Yahav Y, Shoshani T, Abeliovich D, Szeinberg A, Rivlin J, Blau H, Tal A, Ben-Tur L, Highly variable incidence of cystic fibrosis and different mutation distribution among different Jewish ethnic groups in Israel. Hum Genet., 1995; 96(2): 193-197.

18. Konstantinnopoulou S, Tapia EI, Vitamin D and the lung. Paediatr Respir Rev., 2017; 24: 39-43.

19. Lansing AH, McDonald C, Patel RA, Meihls S, Crowell K, Chatfield B, Pohl JF, Vitamin D deficiency in pediatric patients with cystic fibrosis: associated risk factors in the northern United States. South Med J., 2015; 108: 164-169.

20. Lark RK, Lestet GE, Ontjes DA, Blackwood AD, Hollis BW, Hensler MM, Aris RM, Diminished and erratic absorption of ergocalciferol in adult cystic fibrosis patients. Am J Clin Nutr., 2001; 73(3): 602606.

21. Mathiesen IH, Katzenstein TL, Mikkelsen CR, Pressler $\mathrm{T}, \mathrm{p} 20$ inflammation and bone turnover markers in cystic fibrosis. J Cystic Fibros, 2018; 17: S118S119.

22. McCauley LA, Thomas W, Laguna TA, Regelmann WE, Moran A, Polgreen LE, Vitamin D deficiency is associated with pulmonary exacerbations in children with cystic fibrosis. Ann Am Thorac Soc., 2014; 11: 198-204.

23. Mead L, Watson H, Haworth CS, Floto RA, Hand grip strength and DXA in adults with cystic fibrosis. J Cystic Fibros, 2014; 14: S110.

24. Moreau E, Bächer S, Mery S, Le Goff C, Piga N, Vogeser M, Hausmann M, Cavalier E, Performance characteristics of the VIDAS ${ }^{\circledR} 25-\mathrm{OH}$ Vitamin D Total assay - comparison with four immunoassays and two liquid chromatography-tandem mass spectrometry methods in a multicentric study. Clin Chem Lab Med., 2016; 54(1): 45-53.

25. Moustaki M, Loukou I, Priftis NK, Douros K, Role of vitamin $\mathrm{D}$ in cystic fibrosis and non-cystic fibrosis bronchiectasis. World J Clin Pediatr., 2017; 6(3): 132-142.

26. Munteanu D, Negru A, Mihăilescu R, Tilișcan C, Tudor AM, Lazăr M, Aramă ȘS, Ion D, Popescu C, Aramă V, Evaluation of bone mineral density and correlations with inflammation markers in Romanian HIV-positive patients undergoing combined antiretroviral therapy. Farmacia, 2017; 65(1): 114-119.

27. Pincikova T, Paquin-Proulx D, Sandberg JK, Flodström-Tullberg M, Hjelte L, Clinical impact of vitamin D treatment in cystic fibrosis: a pilot randomized, controlled trial. Eur J Clin Nutr., 2017; 71(2): 203-205.

28. Popa I, Pop L, Popa Z, Cilt C, Management guide in mucovisicidoses, Ed Brumar, Timisoara, 2006, 45-52, (available in Romanian).

29. Potts $\mathrm{L}$, Thia LP, Is routine assessment of bone mineral density using dual energy X-ray absorptiometry (DEXA) useful in adolescents with cystic fibrosis $J$ Cystic Fibros, 2017; 16: S133 - S134. 
FARMACIA, 2019, Vol. 67, 3

30. Putman MS, Baker JF, Uluer A, Herlyn K, Lapey A, Sicilian L, Tillotson AP, Gordon CM, Merkel PA, Finkelstein JS, Trends in bone mineral density in young adults with cystic fibrosis over a 15 year period. J Cystic Fibros, 2015; 14(4): 526-532.

31. Rasheed NW, Barbu CG, Florea S, Branceanu G, Fica S, Mitrea N, Dragoi CM, Nicolae AC, Arsene $\mathrm{AL}$, Biochemical markers of calcium and bone metabolism in the monitoring of osteoporosis treatment. Farmacia, 2014; 62(4): 728-736.

32. Regalado LCTR, Porhownik N, Taback S, Oleschuk C, Effect of high dose vitamin $\mathrm{D}_{3}$ therapy on serum vitamin $\mathrm{D}_{3}$ levels in vitamin $\mathrm{D}$ insufficient adults with cystic fibrosis. Clin Nutr ESPEN, 2018; 23: 84-88.

33. Rovner AJ, Stalling VA, Schall JI, Leonard MB, Zemel BS, Vitamin D deficiency in children, adolescent and young adults with cystic fibrosis despite routine oral supplementation. Am. J Clin Nutr., 2007; 86(6): 1694-1699.

34. Sermet-Gaudelus I, Castanet M, Retsch-Bogart G, Aris MR, Update on cystic fibrosis-related bone disease: A special focus on children. Paediatr Respir Rev., 2009; 10(3): 134-142.

35. Sexauer WP, Hadeh A, Ohman-Strickland PA, Zanni RL, Varlotta L, Holsclaw D, Fiel S, Graff GR, Atlas A, Bisberg D, Hadjiliadis D, Michel SH, Mintz D, Chakraborty R, Marra B, Lomas P, Ward T, Sassman M, Imbesi GC, Kitch DM, Mallowe AM, Vitamin D deficiency is associated with pulmonary dysfunction in cystic fibrosis. J Cystic Fibros., 2015; 14: 497-506.

36. Shepherd D, Belessis Y, Katz T, Morton J, Field P, Jaffe A, Single high-dose oral vitamin $\mathrm{D}_{3}$ (stoss) therapy- a solution to vitamin $\mathrm{D}$ deficiency in children with cystic fibrosis. J Cyst Fibros., 2013; 12(2): 177-182.

37. Simoneau T, Sawicki GS, Milliren CE, Feldman HA, Gordon CM, A randomized controlled trial of vitamin $\mathrm{D}$ replacement strategies in pediatric $\mathrm{CF}$ patients. J Cyst Fibros., 2015; 15: 234-241.

38. Smyth AR, Bell SC, Bojcin S, Bryon M, Duff A, Flume P, Kashirskaya N, Munck A, Ratjen F, Schwarzenberg SJ, Sermet-Gaudelus I, Southern KW, Taccetti G, Ullrich G, Wolfe S, European Cystic Fibrosis Society Standards of Care, Best
Practice guidelines. J Cyst Fibros., 2014; 13 (Supp11): S23-42.

39. Tangpricha V, Smith EM, Binongo J, Judd SE, Ziegler TR, Walker S, Tirouvanziam R, Zughaier SM, Lee MJ, Chesdachai S, Hermes WA, Chmiel JF, Gaggar A, Grossmann RE, Joseph PM, Alvarez JA, The Vitamin D for Enhancing the Immune System in Cystic Fibrosis (DISC) trial: Rationale and design of a multi-center, double-blind, placebo-controlled trial of high dose bolus administration of vitamin $\mathrm{D}_{3}$ during acute pulmonary exacerbation of cystic fibrosis. Contemp Clin Trials Commun., 2017; 6: $39-45$.

40. Tangpricha V, Yuquing LJ, Nilo CJ, Binongo G, Judd ES, Michalski SE, LeeSeth JM, Ziegler RT, Tirouvanziam R, Vitamin D for the Immune System in Cystic Fibrosis (DISC): a double-blind, multicenter, randomized, placebo-controlled clinical trial. Am J Clin Nutr., 2019; 109(3): 544-553.

41. Tangripcha V, Kelly A, Stephenson A, Maguines K, Enders J, Robinson KA, Marshall BC, Borowitz D, Vitamin D deficiency. Clinical Care Guidelines, Clin Enocrinol Metab., 2012; 97(4): 1082-1093.

42. Timmers NKLM, Stellato RK, Van der Ent CK, Houwen RHJ, Woestenenk JW, Vitamin D intake, serum 25-hydroxy vitamin $\mathrm{D}$ and pulmonary function in paediatric patients with cystic fibrosis: a longitudinal approach. Br J Nutr., 2019; 121(2): 195-201.

43. Thursfield MR, Naderi K, Leaver N, Rosenthal M, Alton WFWE, Bush A, Davies J, Children with cystic fibrosis demonstrate no respiratory immunological, infective or physiological, consequences of vitamin D deficiency. J Cystic fibros., 2018; 17(5): 657-665.

44. Turck D, Braegger CP, Colombo C, Declercq D, Morton A, Pancheva R, Robberecht E, Stern M, Strandvik B, Wolfe S, Schneider SM, Wilschanski $\mathrm{M}$, ESPEN- ESPGHAN- ECFS guidelines on nutrition care for infants, children, and adults with cystic fibrosis. Clin Nutr., 2016; 35: 557-577.

45. Vanstone MB, Egan ME, Zhang JH, Carpenter TO, Association between serum 25-hydroxyvitamin D level and pulmonary exacerbations in cystic fibrosis. Pediatr Pulmonol., 2015; 50(5): 441-446. 